\title{
CALCULATIONS IN CHEMISTRY: PERMANENT PROBLEM OF STUDENTS AND THEIR TEACHERS
}

\section{Iwona Maciejowska}

\author{
Department of Chemical Education, Jagiellonian University, Krakow, Poland
}

\begin{abstract}
Problems requiring calculation at chemistry lessons cause a peculiar difficulty to students. The bibliography concerning the methods of solving calculus problems is very extensive. Several propositions ((visualisation of an algorithm, teamwork with students-experts and addition of context to text of exercises) verified in practice are described there. They can make easier the teacher work in developing students' skills in solving calculus assignments in chemistry, particularly in classes where chemistry is taught at basic level. But the most important issue is to reflect not "how" but "why" a teacher includes calculus problem in her/his own chemistry lessons.
\end{abstract}

Key words: calculations, teaching in context, chemistry education.

\section{Introduction}

The bibliography concerning the methods of solving calculus problems is very extensive. Some of papers are related to teaching and learning methods used in solving quantitative problems (Stromdahl, 1994), others to teaching resources including those available on-line e.g. an article about the Calculations in Chemistry tutorials published in the ACS newsletter recently (Dahm at al., 2009). Another example might be a paper about the use of tables (Takagishi, 1999). Many authors presented results of pedagogical research concerning comparison of calculus and conceptual test questions (Beall, 1994), classification of chemical calculations according to the complexity of the examples (Švihelová \& Cídlová, 2009) etc.

Importance and popularity of that topic has been supported by books e.g. Calculations for A-Level Chemistry (Ramsden, 1987), Chemical Calculation (Yates, 1997), Handbook of Chemical Engineering Calculations (Chopey, 2003) which has provided some procedures for performing chemical calculations along with fully worked-out examples. At least one of Internet forums is devoted to that issue ${ }^{1}$ as well.

Also in each didactic manual this subject matter is discussed, offering among other things the Poly's method: understanding of the problem, searching for a solution scheme, execution of the scheme, verification of the solution, reconsideration on the solution (Dydaktyka chemii, 2002). In the Poly's method it is explicitly indicated the compelling need of arising students' motivation before they start solving a problem, their intellectual activity, and the necessity to check the correctness of each step made.

For each task students may approach it at least in two ways: either with problem or algorithm nature. Very simply speaking, the problem method requires lying down a hypothesis and its verification while the algorithmic one - finding in the memory an algorithm that would fit to task conditions and using it. These methods, due to their specificity are actually divergent: the problem method is applied mostly when there is no clear-cut solution, and in education, at developing of the so called higher order cognitive skills (HOCS), whereas the algorithmic one - when the way of obtaining solution is available and time determined for carrying out the task is very limited (Toth, 2001).

\footnotetext{
${ }^{1}$ Importance of Calculus in Chemistry.Chemical Forums: A Socratic Model of Chemical Education, http://www.chemicalforums.com/index.php?topic=23186.0 (07.12.2009)
} 


\section{Where is the problem?}

In many publications the statement can be found that problems requiring calculation at chemistry lessons cause a peculiar difficulty to students, and the ways how to cope with this matter are described there (Galska-Krajewska \& Pazdro, 1990).

Analysed are also reasons of a negative attitude of students towards chemical calculations which include such issues as:

- the necessity of the use of skills "from outside of the pigeonhole" of given subject,

- lack of inter-subject correlation (often it is the chemistry teacher who introduces the concept of the percentage or logarithmic function, and not the mathematics one),

- lack of all data in the problem context (the necessity of finding information in outsource data - the periodic table of the elements, electrochemical series, the graph of solubility curves, the values of the dissociation constant tables, etc.).

- the monotony of operations being performed, the lack of motivation.

\section{Calculation in chemistry education at different levels of education}

Teaching chemistry at the junior high school (lower secondary school, gimnazjum) level in Poland is actually of quality nature. Calculations are related to agreeing of summary formulas, reaction equations, both atomic and molecular mass concepts, percentage concentration, solubility, law of conservation of mass and composition stability (facultatively, a concept of the mol and calculations connected with this may be introduced).

In secondary high school (upper secondary school, liceum) classes with the basic profile of teaching chemistry such concepts as the mol, mol concentration, mol volume, dissociation degree, etc. In the extended profile we can already talk of a quantitative approach to the education in chemistry: the dissociation constant value decides of the electrolyte strength, the standard potential value - of the course of reaction with acids or exchange reaction, etc.

\section{Examples of good practice}

Below several propositions verified in practice are described which can make easier the teacher work in developing students' skills in solving calculus assignments in chemistry, particularly in classes where chemistry is taught at basic level.

\section{Visualisation of the algorithm}

Training students in the ability to solve calculus problems in chemistry usually takes place by solving at the blackboard a possible great number of diverse examples, including a spectrum of exercises they can come across, with taking particular note to the necessity of listing given data, searched ones, and with the breakdown of the entire problem into single steps. This method turns out to be useful when evaluating education achievements the student comes across a problem the solution algorithm of which is known to him. To prepare the youth to cope with other types of problems it was decided do deepen the generalisation after a cycle of lessons conducted with this method. The knowledge gained earlier and the creativity of students was exploited and features of the Poly's method as well as the hints contained in available studies were used (Piosik, 1970; Galska-Krajewska at al, 1982). The task posed to student groups was to develop a general algorithm (in the notation used in information technologies and computer science, Fig. 1) of solving calculus problems in chemistry and other natural sciences.

Such classes were conducted in both the so called humanities courses as well as those with the broadened profile of the teaching of mathematics and physics. The visualisation of 
algorithms worked out by students seems to be an interesting didactic aid and despite the algorithm form stimulating the problem approach towards solving assignments. The effectiveness of such a work method requires further investigations.

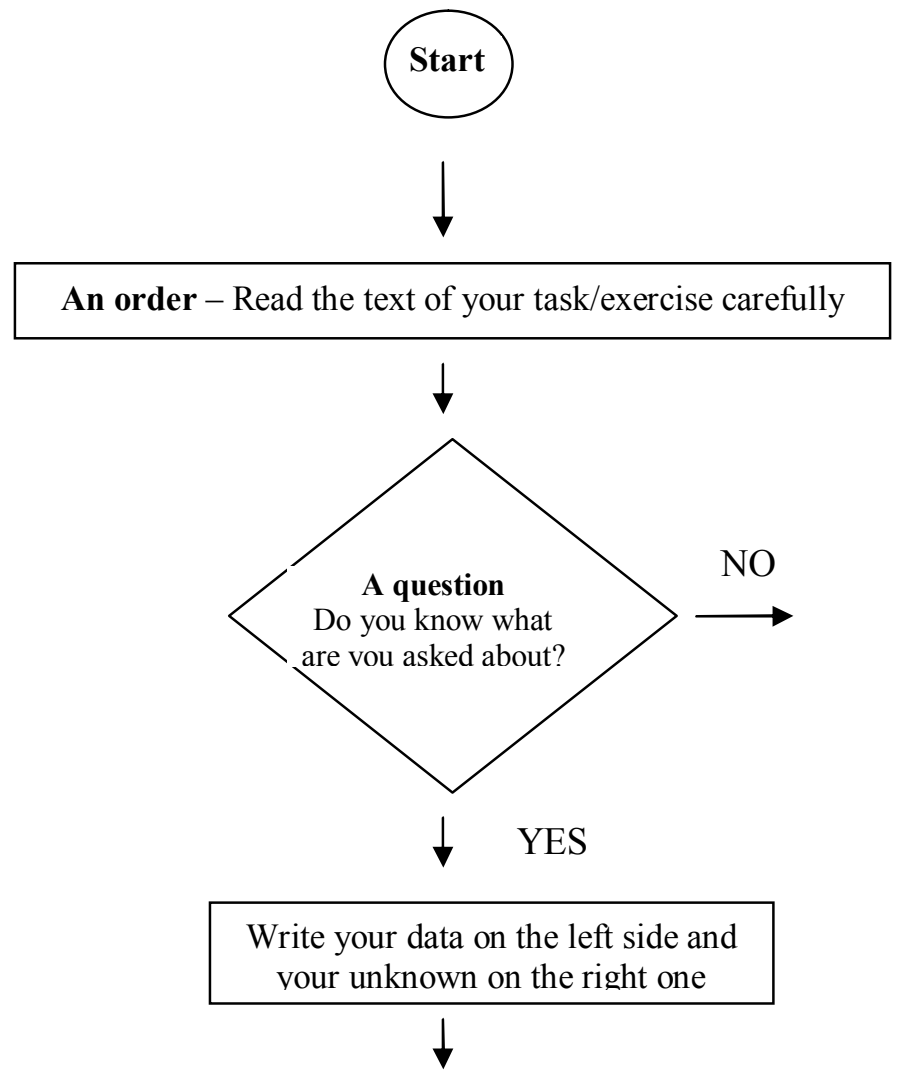

Figure 1. The notation used in information technologies and computer science - an
example.

\section{Expert group}

The basic problem for the teacher during the 2-3 first months of the new school year is the differentiation of the knowledge and skill level of first form students. While some of them have already completed their tasks long ago, the others are still working on them. It was decided to take advantage of this when developing the skills of performance of chemical calculations. After a diagnostic test conducted at the beginning of the school year the teacher picked up a group of students - experts of high knowledge and skill level acquired at their junior high school, and also those who already were well familiar with the mol and mol mass concepts learned at the previous level of their education. These persons were "put at intervals" (as in soccer or tennis tournament) and designated as the managers of student groups. The remaining part of the class was divided evenly. After some introduction to the subject and presenting an exemplary exercise the groups were given calculus tasks. A group manager-expert was to serve the other group members with assistance, guide their work, direct at the correct solution. The results of the group work were always presented by a student who did not fulfil the expert role.

During two years some survey were carried out of the students of humanities classes in one of the secondary school in Krakow who participated in classes conducted with the method 
described above. Below the judgements of both the persons managing the work of groups and regular members of task teams are presented. The order was: "The work in groups with the assistance of a schoolmate (student-expert) was: unnecessary, with no considerable significance, helpful, very helpful (tick one). Justify your answer”.

- "It is easy to communicate with the schoolmate, he/she knows what I cannot understand, even if I cannot express that",

- "The schoolmate explains with more accessible language",

- "When listening to the explanations of my peer I am not under such a big stress",

- "It is easier to obtain information and replies to asked questions",

- No major importance - the expert was delighted with his/her knowledge and excited with the mission of explaining to us",

- "No difference - I prefer to work alone",

- "Explanation to others was very nice and a satisfying occupation",

- "You learn when explaining to others",

- "Many issues have been ordered to me when I was explaining various problems to my school friends".

\section{Context based tasks}

The third way to increase the effectiveness of the teacher work within the development of students' abilities discussed herein is the use of the well known for a long time the principle of combining theory with practice in a somewhat specific form. The talk is about the so called "teaching in context". Whereas within the "pure chemistry" nobody questions the necessity of quoting examples from everyday life, industry, environment protection and conservation, the teachers' and educators' opinions on solving calculus problems are divided. From one hand, with an interesting problem context the motivation increases, hence the work effectiveness increases, too, but from the other - it happens that part of students feels bogged in welldeveloped description of the situation and cannot find out what is really the question. Because at the execution of the basic profile of teaching chemistry the constituent of mathematics in assignments is not very complicated, but it is still considerably discouraging for students of humanities courses, the motivation effect seems to prevail. Therefore, in each exercise to be solved at home or in the class it should be indicated what the required calculations are to be made for. Our goal, at least in the author's opinion, is to educate thinking people, not only ready do fulfil well imposed orders. Examples given below illustrate this principle and are based either on functioning exercise collections ((Sygniewicz \& Koszmider 2002; Pazdro 2004) or come from the author's collections:

A pharmacist needs a hydrogen peroxide solution to disinfect wounds ( $3 \%$ solution of hydrogen peroxide), but only Perhydrol (30\% solution of hydrogen peroxide) was delivered to him. How much Perhydrol in grams he should use to make $100 \mathrm{~g}$ of hydrogen peroxide solution?

You are working in an analysis lab in a big dairy company. Your task is to calculate the content of fat in cow's milk supplied by farmers. What is this content if in $100 \mathrm{~cm}^{3}\left(\mathrm{~d}=1 \mathrm{~g} / \mathrm{dm}^{3}\right)$ of the tested milk you have found 5, $3 \mathrm{~g}$ of fat? 
You have been employed in a small chemical firm. One of your task is to supervise feeders in a mixer where an anti-frost fluid for de-icing of windshields is prepared. Calculate how much ethylene glycol in grams should be fed the feeder to make each $500 \mathrm{~g}$ commercial product batch if the fluid is a $60 \%$ water solution of this compound.

A student's task is to make a synthesis of $\mathrm{NaCl}$ by burning $2.3 \mathrm{~g}$ of sodium in chlorine. Since chlorine is a gas of high toxicity, he should apply a precisely measured volume of this gas. How much of chlorine in $\mathrm{cm}^{3}$ he should let out from the cylinder to the reactor?

Mc Gywer, the hero of many tv movies, is to neutralise hydrochloric acid to be used as the bomb fuse. The bomb will explode when the zinc plate is eaten away by the acid. Mc Gywer has a chemical agent for opening clogged pipes at his disposal. The agent contains $90 \%$ of pure sodium hydroxide. How much this agent our idol should pour in to the container to neutralise $120 \mathrm{~g}$ of the acid with the concentration $=35 \%$ ?

A car owner wants to fill up the car battery with sulphuric acid solution (of concentration $=37 \%)$. To this end he has purchased $1 \mathrm{dm}^{3}$ of concentrated acid $\mathrm{H}_{\mathrm{s}} \mathrm{SO}_{4}(\mathrm{Cp}=70 \%, \mathrm{~d}=1.6$ $\mathrm{g} / \mathrm{cm}^{3}$ ). How much water in grams he/she should add to this volume of the acid?

A chemist was given a gaseous hydrocarbon sample for analysis. She examined its density, it amounted to $1.963 \mathrm{~g} / \mathrm{dm}^{3}$. Then she burned it and obtained $1.008 \mathrm{dm}^{3}$ of carbon dioxide and $1.344 \mathrm{dm}^{3}$ of steam (measured in normal conditions). What summary formula for the examined compound he should put in the report for his client?

One drop of sea water contains about 50 milliards $\left(10^{9}\right)$ of gold atoms. Think, would it be feasible and profitable to recover gold from this source? Calculate how much gold can be obtained from $100 \mathrm{~kg}$ of sea water if one drop weighs about $33 \mathrm{mg}$.

Assignments of this type may concern among other things the dilution of the solutions we encounter in our everyday life (milk, concentrate of washing liquid, fertiliser for flowers) or problems every student or employee can come across in his work life (analyses, lab and industrial syntheses, reaction capacity) and many others.

\section{Summing-up}

Three various suggestions presented there (visualisation of an algorithm, teamwork with students-experts and addition of context to text of exercises) could help secondary school teachers to educate their students in solving calculus problems in chemistry. Each teacher could choose the way he/she prefers to follow and which will fit to his/her student. But the most important issue is to reflect not "how" but "why" I include calculus problem in my own chemistry lessons.

Note. Paper based on a presentation given at XIII School of Chemistry Education Problems, 710 June 2006, Sucha Beskidzka, I.Maciejowska: Zadania obliczeniowe z chemii - parę wskazówek technicznych.

\section{References}

Beall H., Prescott S. (1994). Concepts and Calculations in Chemistry Teaching and Learning. Journal of Chemical Education, Vol. 71, p. 111.

Chopey N. (2003). Handbook of Chemical Engineering Calculations, McGraw-Hill.

Dahm D. J., Mumper M., Nelson E. (2009). Beta-Testing New Approaches For First-Year Chemistry Instruction. In.: Newsletter of the Committee on Computers in Chemical Education, a committee of the Division of Chemical Education of the American Chemical Society. http://www.chemreview.net/CCCEnewsl-DahmMumperNelson.pdf (07.12.2009) 

Poznań

Dydaktyka Chemii. (2002). Eds. A.Burewicz, H. Gulińska. Wydawnictwo Naukowe UAM.

Galska-Krajewska A., Pazdro K.M. (1990). Dydaktyka Chemii. PWN. Warszawa.

Galska-Krajewska A., Szelągowska W., Wiktorzak A. (1982). Rozwiązywanie zadań metodą Polya. Chemia w Szkole, Vol. 28(3), p.136.

Pazdro K.M.(2004). Zbiór zadań dla szkót ponadgimnazjalnych. Oficyna Edukacyjna Krzysztof Pazdro. Warszawa.

Piosik R. (1970). Zastosowanie algorytmów w nauczaniu chemii, artykuł dyskusyjny. Chemia w szkole, Vol. 16 (5), p. 262.

Ramsden E. N. (1987). Calculations for A-Level Chemistry. Stanley Thornes (Publishers) Ltd, $2^{\text {nd }}$ edition.

Švihelová P., Cídlová H. (2009). Classification of Chemical Calculations according to the Complexity of the Examples. In.: International Scientific - Practical - Conference: Chemistry Education 2009. Riga. Latvijas Universitate, p. 147.

Stromdahl H., Tullberg A., Lybeck L. (1994). The qualitatively different conceptions of 1 mol. International Journal on Science Education, Vol. 16(1), p. 17.

Sygniewicz M., Koszmider J. (2002). Chemia. Zbiór zadań dla liceum ogólnokształcącego, liceum profilowanego i technikum. WSiP. Warszawa.

Takagishi Kenji. (1999). The Uses of Tables for Calculations in Chemistry. Chemical Education, Vol. 47, p.58.

Toth Z. (2001). Balancing between Algorythmic and Nonalgorythmic Methods in Solving Chemical Problems. Science and Technology Education: Preparing Future Citizens, Vol. 1, p.133.

Yates P. (1997). Chemical Calculation. CRC Press.

Received 12 September 2009; accepted 21 November 2009

\section{Iwona Maciejowska,}

Assistant professor at the Department of Chemical Education, Faculty of Chemistry, Jagiellonian University, 3 Ingardena Street, 30-060 Kraków, Poland.

Fax: +48126340515 .

E-mail: maciejow@chemia.uj.edu.pl

Website: http://www.uj.edu.pl/index.en.html 